\title{
Role of doppler in fetal growth restriction
}

\author{
Chirag K. Patel*, Parul T. Shah, Rina V. Patel, Kruti J. Deliwala, Rohan Patel, Viral Pandya
}

Department of Obstetrics and Gynaecology, Sheth V.S. General Hospital, Ahmedabad, Gujarat, India

Received: 21 September 2015

Revised: 24 September 2015

Accepted: 30 October 2015

*Correspondence:

Dr. Chirag K. Patel,

E-mail: drchirag.pate19289@gmail.com

Copyright: ( $)$ the author(s), publisher and licensee Medip Academy. This is an open-access article distributed under the terms of the Creative Commons Attribution Non-Commercial License, which permits unrestricted non-commercial use, distribution, and reproduction in any medium, provided the original work is properly cited.

\begin{abstract}
Background: Fetal growth restriction is an important and particularly challenging problem for modern obstetricians and paediatricians. The present study is to correlate the importance of Doppler velocimetry and perinatal outcome in cases of growth restricted foetuses by comparing perinatal outcome of control \& study groups with normal and abnormal Doppler waveforms.

Methods: A study and a control group comprising of 50 pregnant women having growth restricted foetuses in each group was matched for all other confounding factors except for Doppler changes. These patients were followed up and the perinatal outcomes of FGR foetuses having Doppler changes was compared with those having normal

Doppler studies.

Results: In our study, alteration in both MCA and UmbA Doppler was associated with perinatal morbidity and NICU admissions in $64 \%$ and mortality in $28 \%$. Doppler changes showing altered CPR less than 1 had adverse outcome with NICU admission in $61 \%$ and mortality in $34 \%$. Alteration in DV Doppler was associated with perinatal morbidity and NICU admissions in $17 \%$ cases and mortality in $83 \%$ cases, with no pregnancies having a healthy outcome. Among high-risk pregnancies with suspected IUGR, the use of Doppler assessment significantly decreases the likelihood of labor induction, caesarean delivery, and perinatal deaths.

Conclusions: Abnormal Doppler waveform changes indicate adverse perinatal outcome of pregnancies with FGR. Doppler study helps to reduce perinatal mortality and morbidity by timely and appropriate interventions.
\end{abstract}

Keywords: Fetal growth restriction, Umbilical artery Doppler, Middle cerebral artery Doppler, Ductus venosus Doppler, Cerebro placental ratio

\section{INTRODUCTION}

The overall incidence of fetal growth restriction (FGR) varies in different studies but is usually between $3 \%$ and $10 \%$ of all births 1 . In India the incidence of low birth weight varies from 15 to $25 \%$ and more than $50 \%$ of them are FGR. ${ }^{2}$ The growth restricted foetuses are associated with perinatal complications and need monitoring and evaluation.

FGR refers to deviation and reduction in expected fetal growth pattern. Small for gestational age (SGA) infants are those having birth weights below the $10^{\text {th }}$ percentile for their gestational age. Not all FGR infants are small for gestational age. FGR foetuses are classified as symmetric or asymmetric in term of their body proportion. Symmetrically growth restricted foetuses are usually associated with factors that directly impair the intrauterine growth potential of foetus (i.e. chromosomal abnormalities, viral infections etc.) while asymmetric growth restriction is classically associated with uteroplacental insufficiency. ${ }^{3}$ The most common cause for uteroplacental insufficiency is pregnancy induced hypertension.

The preferred radiological examination for evaluating FGR is ultrasonographic examination. These include 
grayscale assessment of parameters of foetal biometry (BPD, FL, AC, HC and EFW). The foetal surveillance is by Doppler study of the umbilical artery (UmbA), middle cerebral artery (MCA) and ductus venosus (DV). FGR is associated with an inadequate quality and quantity of the maternal vascular response to placentation which is shown by the characteristic pathological findings in the placental bed like atheromatous-like lesions that completely or partially occlude the spiral arteries4. Fetal Doppler studies help in identifying the circulatory changes caused by this pathology.

In the growth-restricted fetus, redistribution of welloxygenated blood to vital organs, such as the brain, heart and adrenals, represents a compensatory mechanism to prevent fetal damage. When the reserve capacities of the circulatory redistribution reach their limits, fetal deterioration may occur rapidly. The onset of abnormal venous Doppler results indicates deterioration in the fetal condition and iatrogenic delivery should be considered.

In the sequence of deterioration of the condition of the growth-restricted fetus, the first pathological finding is increased impedance to flow in the umbilical artery signified by the increase in the Umbilical Artery Pulsatility Index (UmbA PI). This is usually associated with evidence of arterial redistribution in the fetal circulation, best monitored by examining the PI in the middle cerebral artery (MCA PI), which is decreased. This results in the fall of Cerebro-Placental Ratio $(\mathrm{CPR}=$ MCA PI / UmbA PI) and, subsequently, the development of pathological fetal heart rate patterns. On average, the time interval between the onset of abnormal umbilical arterial Doppler results and the onset of late fetal heart rate decelerations is about 2 weeks. ${ }^{5-7}$ Hence the most useful diagnostic criteria are umbilical artery PI and cerebro-placental ratio (CPR). ${ }^{8}$

Normal venous flow suggests continuing fetal compensation, whereas abnormal flow indicates the breakdown of hemodynamic compensatory mechanisms. ${ }^{9}$ An abrupt increase in pulsatility of ductus venosus (DV) waveforms with loss of forward flow velocity during atrial contraction precede the onset of pathological fetal heart rate patterns and decreased short-term variation. This interval may be as short as a few hours to few days before intrauterine death occurs.

The aim of fetal and maternal surveillance in the case of fetal growth restriction may be summarized as the need to optimize the timing of delivery before death of the fetus in the uterus or before it undergoes permanent damage. The importance of our study is to draw attention of the clinicians to the importance of Doppler study in the management of FGR and its role in decision making regarding the further course of the pregnancy and timing of delivery. Timely intervention can help in the better perinatal outcome of pregnancy.

\section{METHODS}

The study was conducted at Obstetrics department of Sheth V.S. General Hospital, Ahmedabad, Gujarat, India between 1st July 2014 and 1st July 2015. Cases were sampled according to the inclusion and exclusion criteria from all the third trimester singleton pregnancies with FGR attended to at our department and their Doppler examination was done. Analysis of spectral waveforms and pulsatility (PI) of umbilical artery, middle cerebral artery and ductus venosus was done. Total sample was split in to 2 groups of 50 each depending on their Doppler findings. Group A $(n=50)$ included patients with FGR having altered Doppler. Group B $(n=50)$ comprised of patients with FGR and normal Doppler indices. Data was collected which included diagnosis to delivery interval, gestational age at birth, admission to neonatal intensive care, morbidity and mortality if any. Pregnancy with diabetes, pregnancies with other associated chronic maternal conditions and foetuses having congenital anomalies were excluded.

Informed consent was taken from all the pregnant patients included in the study. The pregnancies were dated by a combination of last menstrual period and the first trimester dating scan. The diagnosis of FGR was made clinically and confirmed subsequently on ultrasound, when foetal abdominal circumference and estimated foetal weight was below 10th centile for the gestational age.

\section{RESULTS}

Table 1: Relationship of altered Doppler and perinatal outcome.

\begin{tabular}{|llll|} 
& $\begin{array}{l}\text { Morbidity } \\
\text { (requiring } \\
\text { NICU } \\
\text { Admission) }\end{array}$ & $\begin{array}{l}\text { Mortality } \\
\text { even after } \\
\text { NICU } \\
\text { admission }\end{array}$ & Healthy \\
\hline $\begin{array}{l}\text { Altered } \\
\text { UmbA PI } \\
(n=47)\end{array}$ & $26(55 \%)$ & $09(19 \%)$ & $12(26 \%)$ \\
\hline $\begin{array}{l}\text { Altered } \\
\text { MCA PI } \\
(n=40)\end{array}$ & $23(58 \%)$ & $09(22 \%)$ & $08(20 \%)$ \\
\hline $\begin{array}{l}\text { Both UmbA } \\
\text { and MCA PI } \\
(n=42)\end{array}$ & $27(64 \%)$ & $12(28 \%)$ & $03(08 \%)$ \\
\hline $\begin{array}{l}\text { Altered DV } \\
\text { Doppler } \\
(n=12)\end{array}$ & $02(17 \%)$ & $10(83 \%)$ & $00(00 \%)$ \\
\hline
\end{tabular}

\section{DISCUSSION}

Altered UmbA Doppler is associated with perinatal morbidity and NICU admissions in $55 \%$ cases and mortality in $19 \%$ cases. Altered MCA Doppler is associated with perinatal morbidity and NICU admissions 
in $58 \%$ cases and mortality in $22 \%$ cases. Alteration in both MCA and UmbA Doppler is associated with perinatal morbidity and NICU admissions in 64\% cases and mortality in $28 \%$ cases. These results are comparable with other studies which have mortality rate of about $22 \%$ and morbidity rate of $62 \%$. $^{9}$

Table 2: CPR and perinatal outcome.

\begin{tabular}{|llll|} 
& $\begin{array}{l}\text { Morbidity } \\
\text { (requiring } \\
\text { NICU } \\
\text { Admission) }\end{array}$ & $\begin{array}{l}\text { Mortality } \\
\text { even after } \\
\text { NICU } \\
\text { admission }\end{array}$ & Healthy \\
\hline $\begin{array}{l}\mathrm{CPR}>1 \\
(\mathrm{n}=64)\end{array}$ & $27(42 \%)$ & $05(08 \%)$ & $\begin{array}{l}32 \\
(50 \%)\end{array}$ \\
\hline $\begin{array}{l}\mathrm{CPR}<1 \\
(\mathrm{n}=36)\end{array}$ & $22(61 \%)$ & $12(34 \%)$ & $\begin{array}{l}02 \\
(05 \%)\end{array}$ \\
\hline Total & 49 & 17 & 34 \\
\hline
\end{tabular}

Table 3: Time of delivery.

\begin{tabular}{|lll|l|} 
& $<33$ weeks & $33-37$ weeks & $>37$ weeks \\
\hline Group A & $34(68 \%)$ & $12(24 \%)$ & $4(8 \%)$ \\
\hline Group B & $22(44 \%)$ & $19(38 \%)$ & $9(18 \%)$ \\
\hline
\end{tabular}

Table 4: Mode of delivery.

\begin{tabular}{|lll|}
\hline Group A & LSCS & Normal Delivery \\
\hline Group B & $41(82 \%)$ & $9(18 \%)$ \\
\hline Total & $29(58 \%)$ & $21(42 \%)$ \\
\hline
\end{tabular}

Table 5: Perinatal morbidity and mortality.

\begin{tabular}{|lll|} 
& $\begin{array}{l}\text { Neonatal Intensive } \\
\text { Care admission }\end{array}$ & $\begin{array}{l}\text { Perinatal } \\
\text { Mortality }\end{array}$ \\
\hline Group A & $30(60 \%)$ & $14(28 \%)$ \\
\hline Group B & $19(38 \%)$ & $3(6 \%)$ \\
\hline Total & 49 & 17 \\
\hline
\end{tabular}

According to Gramellini et al, the cerebral-placental Doppler ratio provided a better predictor of adverse perinatal outcome for FGR new-borns than either the MCA or UmbA alone. In our study, the Doppler changes showing altered CPR less than 1 had adverse outcome with NICU admission in $61 \%$ and mortality in $34 \%$ cases, which correlated well with other studies. ${ }^{10}$

Alteration in DV Doppler is associated with perinatal morbidity and NICU admissions in $17 \%$ cases and mortality in $83 \%$ cases, with no pregnancies having a healthy outcome. These results are congruent with the study by Gudmundsson et al, where they have noted $80 \%$ mortality in foetuses with altered DV Doppler. ${ }^{11}$

In our present study, in $82 \%$ of the cases, delivery was conducted by LSCS as compared to $58 \%$ in the control group. Normal delivery was conducted in $18 \%$ of the cases compared to $42 \%$ in the control group. These results are comparable with Lakhakar et al, showing $62 \%$ of caesarean rate in abnormal Doppler and 38\% vaginal birth in their study. ${ }^{9}$

In accordance with the results of our study, a systematic review of other Doppler studies indicates that among high-risk pregnancies with suspected IUGR, the use of Doppler assessment significantly decreases the likelihood of labor induction, caesarean delivery, and perinatal deaths. Antepartum surveillance with Doppler should be started when the fetus is viable and IUGR is suspected, which can help improve the perinatal outcome of the fetus. $^{12-14}$

\section{CONCLUSIONS}

Doppler velocimetry is the key for early detection, prompt follow up, and timely decision making in management of FGR. Doppler allows better understanding of hemodynamic changes in fetoplacental and uteroplacental circulation associated with growth restricted foetuses. As changes in umbilical and middle cerebral artery circulation strongly correlate with pregnancy outcome, Doppler is a primary tool for fetomaternal surveillance in these pregnancies.

Study of middle cerebral artery is as important as umbilical artery in term of neonatal outcome. The cerebro-placental ratio (CPR), which measures the proportion of flow supplying the brain and placenta, is one of the most powerful parameters for assessment of FGR and hypoxia as it takes into account the cause and consequences of placental insufficiency. If CPR is less than 1 , there is not only a high rate of perinatal loss, but the surviving fetus demonstrates signs of profound compromise. If umbilical and middle cerebral artery Doppler indices are positive then the study should be extended to other fetal vessels like ductus venosus. Abnormal ductus venosus Doppler signifies impending fetal compromise and imminent fetal distress and such pregnancies should be considered for urgent iatrogenic termination.

Funding: No funding sources

Conflict of interest: None declared

Ethical approval: The study was approved by the Institutional Ethics Committee

\section{REFERENCES}

1. Middleton W, Kurtz AB, and Hertzberg BS in: Ultrasound: The Requisites, 2nd ed. Mosby. 2004:330-41.

2. Saraiya UB, Rao KA, Chatterejee A, Principles and Practice of Obstetrics and Gynecology for Postgraduates 2nd ed. Jaypee. 2003:112.

3. Baker PN, Kenny L. Obstetrics by ten teachers, 18th ed. London: Hodder Arnold. 2006:156-70. 
4. Sheppard BL, Bonnar J. An ultrastructural study of utero-placental spiral arteries in hypertensive and normotensive pregnancy and fetal growth retardation. Br J Obstet Gynaecol. 1981;88:695-705.

5. Reuwer PJ, Sijmons EA, Rietman GW, van Tiel MW, Bruinse HW. Intrauterine growth retardation: prediction of perinatal distress by Doppler ultrasound. Lancet. 1987;22:415-18.

6. Arabin B, Siebert M, Jimenez E, Saling E. Obstetrical characteristics of a loss of end-diastolic velocities in the fetal aorta and/or umbilical artery using Doppler ultrasound. Gynecol Obstet Invest. 1988;25:173-80.

7. Karowicz-Bilińska A, Sieroszewski P, KowalskaKoprek U. The value of Doppler velocimetry in umbilical and cerebral artery in pregnancy complicated by IUGR and its influence on mode of delivery and neonatal Apgar score. Ginekol Pol. 2006;77(12):945-51.

8. Hecher K, Hackeloer BJ. Cardiotocogram compared to Doppler investigation of the fetal circulation in the premature growth-retarded fetus: longitudinal observations. Ultrasound Obstet Gynecol. 1997;9:152-61

9. B.M. Lakhakar, H.V. Rajgopal P.T. Gourishankar. Doppler prediction of adverse perinatal outcome in $\mathrm{PIH}$ and IUGR. Indian Jn of Radiology. 2006;16:2006,109-16.
10. Gramellini D, Folli MC, Raboni S, Vadora E, Merialdi A. Cerebral - Umbilical Doppler Ratio As a Predictor of Adverse Perinatal Outcome. Obstetrics and Gynaecology. 1992;79:416-20.

11. Gudmundsson S, Tulzer G, Huhta JC. Venous Doppler in the foetus with absent end diastolic flow in the umbilical artery. Ultrasound Obstet Gynecol. 1996;7:262-7.

12. Berkley E, Chauhan SP, Abuhamad A. Doppler assessment of the fetus with intrauterine growth restriction. AJOG. 2012;206:4:300-308.

13. Rizzo G, Capponi A, Arduini D, Romanini C. the value of fetal arterial, cardiac and venous flows in predicting $\mathrm{pH}$ and blood gases measured in umbilical blood at cordocentesis in growth retarded foetuses. BJOG. 1995;102: 963-9.

14. Fong KW, Ohlsson A, Hanah Me, Kingdom J, et al. Prediction of Perinatal Outcome in Foetuses Suspected to Have Intrauterine Growth Restriction. Radiology. 1999;213:681-9.

Cite this article as: Patel CK, Shah PT, Patel RV, Deliwala KJ, Patel R, Pandya V. Role of doppler in fetal growth restriction. Int J Reprod Contracept Obstet Gynecol 2015;4:1922-5. 